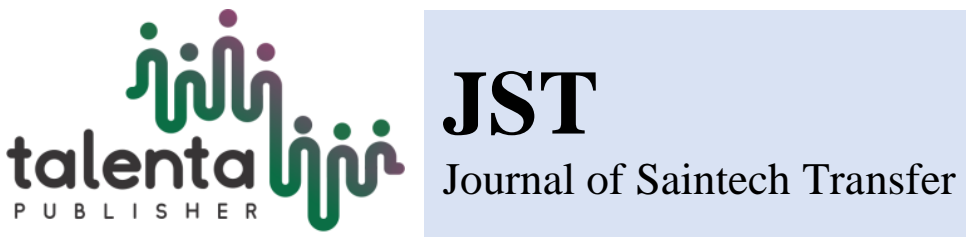

\title{
The Production of Fo Oyster Mushroom Seeds (Pleurotus ostreatus), The Post-Harvest Handling, and The Utilization of Baglog Waste into Compost Fertilizer
}

\author{
Maimunah Siregar", Abdul Hadi Idris \\ Department of Agroecotechnology, Faculty of Agriculture, University of Pembangunan Panca Budi
}

\begin{abstract}
Community service is one of the duties that must be carried out by every lecturer in Higher Education as one aspect of Tri Dharma University. This community service was titled "The Production of F0 Oyster Mushroom Seeds (Pleurotus ostreatus), The Post-Harvest Handling, and The Utilization of Baglog Waste into Compost" which involved two partners. Partner 1 was in Pegajahan Village, Pegajahan Sub-District who experienced problems with the availability of high-quality F0 and F1 seeds and low production in terms of quality and quantity. Partner 2 was in Blok $\mathrm{H}$ Village Dolok Masihul Sub-District, Serdang Bedagai Regency who had a lack of knowledge about post-harvest handling and composting from oyster mushroom baglog waste. Solutions offered for both partners were: (1) transfer of knowledge, such as lectures and discussions; (2) training; and (3) mentoring about the cultivation of F0 and F1 oyster mushrooms. Goals and targets of this activity were: (1) the communities or the farmer groups were able to produce and cultivate F0 and F1 oyster mushrooms, so they did not need to buy F0 and F1 seeds from other regions and can fulfill the market demand; and (2) Partner 2 was able to make compost from oyster mushroom baglog waste and various processed food from oyster mushroom to increase their income. The results of this activity have provided benefits to Partner 1 regarding their ability to produce F0 and F1 seeds, ability to process post-harvest oyster mushrooms into several types of food to increase its selling value, and ability to make compost from baglog waste which can be used for plants to overcome environmental pollution and to increase Partner 2's income.
\end{abstract}

Keywords: F0 Seeds, Oyster Mushroom, Post-harvest, Compost

Abstrak. Pengabdian pada masyarakat merupakan salah satu kewajiban yang harus dilaksanakan oleh setiap dosen di Perguruan Tinggi sebagai salah satu aspek Tri Dharma Perguruan Tinggi. Kegiatan pengabdian ini berjudul "Pembuatan Bibit FO Jamur Tiram (Pleorotus ostreatus) dan Penanganan Pasca Panen Serta Pemanfaatan *Corresponding author at: Jalan. Gatot Subroto KM 4.5 Medan 20122, Indonesia

E-mail address:maimunahsiregar17@gmail.com 
Limbah Bag Log Menjadi Pupuk Kompos” melibatkan dua mitra, yaitu Mitra 1 di Desa Pegajahan, Kecamatan Pegajahan mempunyai masalah dengan ketersediaan bibit FO dan F1 yang berkualitas dan produksi yang rendah dari segi kualitas maupun kuantitas dan Mitra 2 di Desa Blok H Kecamatan Dolok Masihul Kabupaten Serdang Bedagai mempunyai masalah kurangnya pemahaman tentang penanganan pasca panen dan pembuatan kompos dari limbah Bag Log Jamur Tiram. Solusi untuk kedua Mitra tersebut, berupa : 1) transfer pengetahuan seperti ceramah dan diskusi, 2). pelatihan, dan 3). pendampingan tentang pembuatan FO dan F1 jamur tiram. Tujuan dan target yang ingin dicapai pada kegiatan ini seperti :1). masyarakat/kelompok tani dapat membuat FO dan F1 serta membudidayakan jamur tiram dengan baik sehingga tidak membeli bibit FO dan F1 dari daerah lain, dan dapat memenuhi permintaan pasar, 2). Mitra 2 dapat membuat kompos dari limbah Bag Log Jamur Tiram dan dapat membuat berbagai olahan pangan dari jamur tiram sehingga dapat meningkatkan pendapatannya. Hasil kegiatan telah memberikan manfaat kepada Mitra I berupa kemampuan membuat bibit FO dan F1, mampu mengolah pasca panen jamur tiram menjadi beberapa jenis panganan sehingga nilai jual semakin tinggi dan mampu membuat pupuk kompos dari limbah bag log untuk mengatasi pencemaran lingkungan yang dapat diaplikasi ke tanaman sehingga meningkatkan pendapatan untuk mitra II.

Kata kunci : Bibit F0, Jamur Tiram, Pasca Panen, Kompos

Received 22 October 2017 | Revised 10 December 2017 | Accepted 9 March 2018

\section{Introduction}

Serdang Bedagai Regency has an area of $1,900.22 \mathrm{~km}^{2}$ consisting of 17 sub-districts and 243 villages, and most of its population income is derived from paddy. One of the 17 sub-districts is Pegajahan Sub-District. One of the villages in Pegajahan Sub-District, named Pegajahan Village, is a village well-known for its paddy harvest, and it also has a farmer group of oyster mushrooms. Generally, the villagers in Pegajahan work as farmers. The paddy field area in Pegajahan Sub-District was 1,472 Ha in 2009-2012, but it was reduced to 1,464 Ha in 2013. The average production of rice in Pegajahan Sub-District is $55.91 \mathrm{~kW} / \mathrm{Ha}$ [1]. Pegajahan Sub-District is bordered by Deli Serdang Regency on the east side, Serbajadi Sub-District on the south side, Sei Rampah Sub-District on the west side, and Perbaungan Sub-District on the north side.

Generally, people in Serdang Bedagai Village work as farmers, entrepreneurs, and traders. One of the most prospective and potential agriculture businesses is cultivation business of oyster mushroom (Pleurotus ostreatus) in Pegajahan Village and Blok H Dolok Masihul Hamlet because of several reasons, such as: 
1. Market absorption is extremely high and increasing.

2. A possibility of market stagnation is very small because it is part of the daily consumption of the community

3. The raw material is easy to get and cheap

4. Maintaining process is relatively easy

5. Does not require extensive land

6. Skill requirements are not high

7. Oyster mushroom can be cultivated throughout all season, so it can generate continuous profit throughout the year.

8. Oyster mushroom is a delicious, healthy, and highly nutritious alternative food which does not cause environmental pollution.

9. Baglog used for planting media can be used for fish pond fertilizers, fish feed mixtures, animal feed mixtures, media to keep worms, and can be used as compost fertilizer.

Oyster mushrooms (Pleurotus ostreatus) are edible mushrooms from Basidiomycota group and belongs to Homobasidiomycetes class with general characteristics of creamy white body and its semicircular hood resembling an oyster shell with a slightly concave center portion. Naturally, oyster mushrooms (Pleurotus ostreatus) are found in the forest under broad-leaved trees or under woody plants. Oyster mushrooms do not require much sunlight; in a sheltered place, mycelium fungus grows faster than in a bright place with abundant sunlight. Oyster mushroom contains water, iron fiber, calcium, vitamin B1, vitamin $\mathrm{B} 2$, vitamin $\mathrm{C}$, high protein, rich in vitamins and minerals, and low level of carbohydrates, fats, and calories. The composition and nutritional content of every 100 grams of oyster mushrooms are 367 calories, $10.5-30.4 \%$ of protein, $56.6 \%$ of carbohydrates, $1.7-2.2 \%$ of fat, $0.20 \mathrm{mg}$ of thiamin, $4.7-4.9 \mathrm{mg}$ of riboflavin, $77.2 \mathrm{mg}$ of niacin, and $314.0 \mathrm{mg}$ of calcium. The calories contained in this mushroom are 100 $\mathrm{kj} / 100$ grams with $72 \%$ of saturated fat. Mushroom fiber is highly beneficial for the digestive system. The fiber content reaches $7.4-24.6 \%$ which is suitable for people who diet. Other benefits for health are that it can reduce cholesterol, weak heart, and some other diseases. This mushroom is also believed to have medicinal properties for various diseases, such as liver, diabetes, and anemia [2].

The enterprise of Partner 1, Poktan Oyster Mushroom Bintang (Mr. Nyoman Budi A), in Pegajahan Village was still a simple and less intensive cultivation of oyster mushrooms due to the lack of knowledge about a good cultivation of oyster mushrooms, so contamination happened. The average production results in a day were about $10 \mathrm{~kg}$. This production was still far below the market demand whereas the marketing prospects looked promising. The business opportunity and the market demand for this mushroom were huge due to the increasing 
awareness of health values. Partner 1 expressed a desire to develop its oyster mushroom cultivation in order to increase their production and income. Other obstacles experienced by Partner 1and the people in this village were a bad way of oyster mushroom cultivation and frequent baglog contamination which caused low production and low quality of seeds available.

Partner 2, Poktan Oyster Mushroom Domas (Mr. Edi Perianto), is a traditional oyster mushroom farmer from Blok H Dolok Masihul Village. This village is approximately $20 \mathrm{~km}$ from the district capital. The main livelihood of Partner 2 and most people in Blok H Dolok Masihul Village is as traditional farmers with a low income. Therefore, Partner 2 was eager to earn additional income by cultivating oyster mushroom professionally. To date, the quality of mushrooms produced was very low, and it was usually sold at a low price or just consumed by the people in the village. Partner 2 expected to the Proposing Team to gain the knowledge of the post-harvest process of oyster mushrooms and the ways of marketing to increase their selling value. The processed products from oyster mushroom are snacks, nuggets, meatballs, and crispy oyster mushroom. Baglog waste from mushrooms can be processed to be composted; thus, the mushroom farmers in Blok $\mathrm{H}$ can increase their income by marketing their products in the form of several types of food and compost which can be sold to farmers of rice and vegetables in the village.

\subsection{Partner Problems}

Based on the description of above, it can be concluded that the main problems of Partner 1 were:

(1) Lack of understanding about the good cultivation techniques of oyster mushrooms.

(2) Kumbung building (house of mushrooms) did not meet the requirements of oyster mushrooms cultivation.

(3) Lack of knowledge of the farmers regarding the sterilization process, so not all bags of mushroom were successfully sterilized.

(4) The absence of special training about oyster mushroom cultivation techniques.

(5) Unable to produce high-quality F0 seeds to increase the production of oyster mushroom.

(6) Low average production per day which was about $10 \mathrm{~kg}$.

The main problems of Partner 2 were:

(1) Lack of fresh mushroom marketing strategies.

(2) Lack of understanding about the benefits of oyster mushrooms consumption.

(3) Lack of understanding about the post-harvest processing of oyster mushrooms. 


\section{Method}

Based on the problems experienced by Partner 1and Partner 2 and also in accordance with the expertise of the Proposer / Implementing Team of activities and agreements with both partners, the activity was conducted for a period of 8 months. The solution approach was to solve production aspects issues, especially those related to low-quality products, low quantity of crops, and dependence of F0 oyster mushroom seeds from Java (Partner 2). The procedures to support problem solving methods were by training, education, and mentoring (Partner 1 and Partner 2).

Since the activity was conducted for only 8 months, it was expected that after this community service was finished, both partners could independently cultivate oyster mushrooms well, produce good quality F0 seeds, and conduct the post-harvest processing and marketing of the oyster mushrooms well. Both Partners and the Implementing Team would be gathered in one place to provide the materials as well as the direct practice in accordance with the issues to be resolved. To solve the problem, the activity plan that would be performed was :

Activity 1. Conducted the application of science and technology on seed production consisting of:

a. Transfer of knowledge (education) about how to choose a good oyster mushroom to be used as F0 seeds and F1 seeds.

b. Transfer of knowledge (education) about the equipments and materials required for making F0 and F1 seeds.

c. Training of sterilization methods oftools and rooms .

d. Training of F0 and F1 seeds culture media.

e. Training of F0 and F1 seeds production.

f. Facilitating observation of the success of F0 and F1 seeds.

g. Assisting for removal of F0 and F1 seeds.

Activity 2. Conducted assistance on the cultivation aspect to improve the quality and quantity of crops.

a. Training and discussion of cultivation starting from the planting of F1 seeds to a good way of harvesting.

b. Training of the processing of oyster mushroom harvest into several food products, so that it can increase its selling value in the community.

Training of oyster mushroom waste handling as a raw material of compost fertilizer and to overcome environmental pollution. 


\section{Results and Discussion}

\subsection{Location of Survey}

On 25 March2017, the implementation team conducted a site survey. On this occasion, theteam met Partner 1 (Mr. Nyoman Budi A) and Partner 2 (Mr. Edi Priyanto). This activity wasaimed to discuss plan activities of community service, such as lectures on the production of F0 and F1 oyster mushroom seeds, room improvements for F0 and F1 mushrooms production, training and assistance for the production of oyster mushroom seeds, post-harvest handling of oyster mushrooms (processing), and composting from oyster mushrooms baglog waste. In this meeting, the time and place for the community service activity were agreed.

\subsection{Lecture on The Production of Oyster Mushroom Seeds}

The lecture on the production of oyster mushroom seeds was held on 12 August 2017 for Partner 1 (Mr. Nyoman Budi A) in Pegajahan Village, Serdang Bedagai. This event was attended by Partner 1, Partner 2, and neighbors of Partner 1. Prior to the lecture, the participants were given a questionnaire about oyster mushrooms. The questionnaire was aimed to know the level of knowledge of the farmers about oyster mushrooms. The results of this questionnaire are summarized in Table 1 and 2. The lecture materials were about the production ofF0 and F1 oyster mushroom seeds.

\subsection{Lecture on Processing Oyster Mushroom into Several Types of Food and Making Compostfrom Oyster Mushrooms Baglog Waste}

The lecture on processing oyster mushroom into several types of food and composting from oyster mushrooms baglog waste was conducted on 13 August 2017 at the residence of Partner 2 (Mr. Edi Priyanto) in Blok H Village, Dolok Masihul. This event was attended by Partner 1, Partner 2, and the neighbors of Partner 2.

For each lecture material, material modules were provided for participants. The first materials of the lecture were about the good cultivation of oyster mushrooms, growing requirements, marketing prospects of oyster mushrooms, good characteristics of mushroom, and how to make oyster mushroom seeds. The aim of these materials was that participants, who were interested in the production of oyster mushrooms or would like to develop their business, were no longer dependent on the seeds from Java. The second materials provided an explanation of how the processing of oyster mushrooms 
was made into several types of food; thus, it might raise the income of the mushroom farmers. In addition to the second materials, the way of making compost fertilizer from oyster mushroom baglog waste was delivered. It will overcome the environmental pollution from existing (unused) baglog wastes. Furthermore, composting might also increase the farmers' income and soil fertility of people who used these composted waste on their crops. During this activity, all participants were enthusiastic and interested in the contents of the lecture. It could be seen from the number of attended participants, the seriousness of the participants, and an enthusiast question and answer session.

Table 1. General information of the participants who attended the oyster mushroom cultivation

\begin{tabular}{|c|c|c|}
\hline No & Participants & Percentage $(\%)$ \\
\hline \multicolumn{3}{|c|}{ Sex } \\
\hline 1 & Female & 70 \\
\hline 2 & Male & 30 \\
\hline \multicolumn{3}{|c|}{ Age } \\
\hline 3 & Under 30 years old & 35 \\
\hline 4 & $30-40$ years old & 30 \\
\hline 5 & $40-50$ years old & 30 \\
\hline 6 & Above 50 years old & 5 \\
\hline \multicolumn{3}{|c|}{ Education } \\
\hline 7 & Senior High School & 45 \\
\hline 8 & University & 20 \\
\hline 9 & Junior High School & 20 \\
\hline 10 & Not in school & 10 \\
\hline \multicolumn{3}{|c|}{ Occupation } \\
\hline 11 & Unemployment & 55 \\
\hline 12 & Private Employees & 20 \\
\hline 13 & Government Employees & 5 \\
\hline 14 & Others & 20 \\
\hline
\end{tabular}

\subsection{Room Improvement to Produce F0 and F1 Oyster Mushroom Seeds}

The next activity was room improvement for F0 and F1 oyster mushrooms production on the land owned by Partner 1 in Pegajahan Village. These improvements were intended as a training place for the production of oyster mushroom seeds (F0 and F1). This room was equipped with laboratory equipment. The process of providing seeds will be performed in this room (as a place of inoculation). Room improvement was done on 10 August 2017. 
Table 2. Basic knowledge of participantsabout oyster mushroom

\begin{tabular}{|c|c|c|}
\hline No & Information asked & Answer (\%) \\
\hline \multicolumn{3}{|c|}{ Get to know osyter mushroom } \\
\hline 1 & Less than 1 year & 30 \\
\hline 2 & $1-5$ years & 45 \\
\hline 3 & Above 5 years & 20 \\
\hline 4 & N/A & 5 \\
\hline \multicolumn{3}{|c|}{ Oyster mushroom information obtained } \\
\hline 5 & Neighbors/Friends & 70 \\
\hline 6 & TV & 20 \\
\hline 7 & Know by themselves & 1 \\
\hline \multicolumn{3}{|c|}{ Own an oyster mushroom business } \\
\hline 8 & Yes & 70 \\
\hline 9 & No & 20 \\
\hline 10 & N/A & 10 \\
\hline \multicolumn{3}{|c|}{ Seeds source } \\
\hline 11 & Purchased from Java & 30 \\
\hline 12 & Purchased from North Sumatra & 15 \\
\hline 13 & Purchased from friends & 25 \\
\hline 14 & Produced by themselves & 0 \\
\hline 15 & N/A & 30 \\
\hline \multicolumn{3}{|c|}{ Serious Problems Faced } \\
\hline 16 & Seeds Provision & 50 \\
\hline 17 & Heat & 40 \\
\hline 18 & Others & 10 \\
\hline
\end{tabular}

\subsection{Training, Assistance, and Grant Provision for Partner 1}

After the room improvement was completed, the training was then conducted in which the activity was focused on Partner 1, namely:

1. Training on how to sterilize tools and making media for F0

2. Training on the inoculation of oyster mushroom seeds on the media that have been provided

3. Training on inoculation of F0 seeds to corn medium to obtain F1 derivative

At this stage of assistance, Partner 1 was trained on how to sterilize the tools which will be used to prepare F0 in autoclave. Next, Partner 1 was trained on making F0 media (PDA = Potatoes Dextrose Agar) and sterilizing the media, which was also conducted in autoclave. After the preparation of the media was done, Partner 1 learnt how to select good quality oyster mushrooms which will be used in the production of F0 seeds and was also trained on how to inoculate oyster mushrooms to be F0 seeds. Furthermore, after F0 seeds grew, F0 was inoculated on a corn medium to obtain F1 seeds.

The results showed that Partner 1 have understood how to sterilize the tools and materials used in the production of F0, how to choose high quality mushrooms, how to make PDA media, and how to to inoculate mushrooms on the PDA media. It was expected that there would be no further obstacles in the production of F0 and F1 oyster mushroom seeds. Therefore, Partner 1 do not need to buy seeds from others because they are able produce by themselves. 


\section{Training, Assistance, and Grant Provision for Partner 2}

The training, assistance, and grants provided for Partner 2 were related to post-harvest activities of oyster mushrooms. Partner 2 was trained to produce some types of food processed from oyster mushrooms, such as nugget, meatballs, crispy mushroom, and burgers. Other activities were focused on the utilization process of baglog waste into compost fertilizer. First, the oyster mushrooms baglog waste was smoothed, then mixed with the livestock feces. After that, the EM4 solution was added with a mixture of brown sugar and one liter of water. This solution was sprayed and stirred evenly on the baglog waste and livestock feces. The baglog waste and EM4 mixture were then cured for 14 days with the temperature less than 50 degrees Celsius.

\subsection{Monitoring of Community Service Results}

\subsubsection{Production of F0 and F1 oyster mushroom seeds}

The team of the community service conducted a monitoring activity to the implementation of community service activities which have been carried out, started from the survey to the production of F0 and F1 oyster mushrooms seeds done by Partner 1, which can be seen in Table 3 and Figure 1.

\subsubsection{Post-harvest processing of oyster mushrooms}

The transfer of information were about post-harvest processing of oyster mushrooms and baglog waste utilization into compost on Partner 2. The aim of the monitoring activity was to investigate the level of knowledge of Partner 2 after the activity was conducted. The results of the monitoring were described in Table 4.

Table 3. Level of Knowledge of Partner 1 Before and After The Training

\begin{tabular}{|c|c|c|}
\hline Training & Before & After \\
\hline $\begin{array}{l}\text { Choosing high quality } \\
\text { mushrooms to be the seeds }\end{array}$ & Did not know & Understand and can apply \\
\hline $\begin{array}{l}\text { The sterilization process of the } \\
\text { tools and materials to produce F0 } \\
\text { seeds }\end{array}$ & Did not know & Understand and can apply \\
\hline $\begin{array}{l}\text { The inoculation of F0 and F1 } \\
\text { seeds in certain media }\end{array}$ & Did not know & Understand and can apply \\
\hline
\end{tabular}



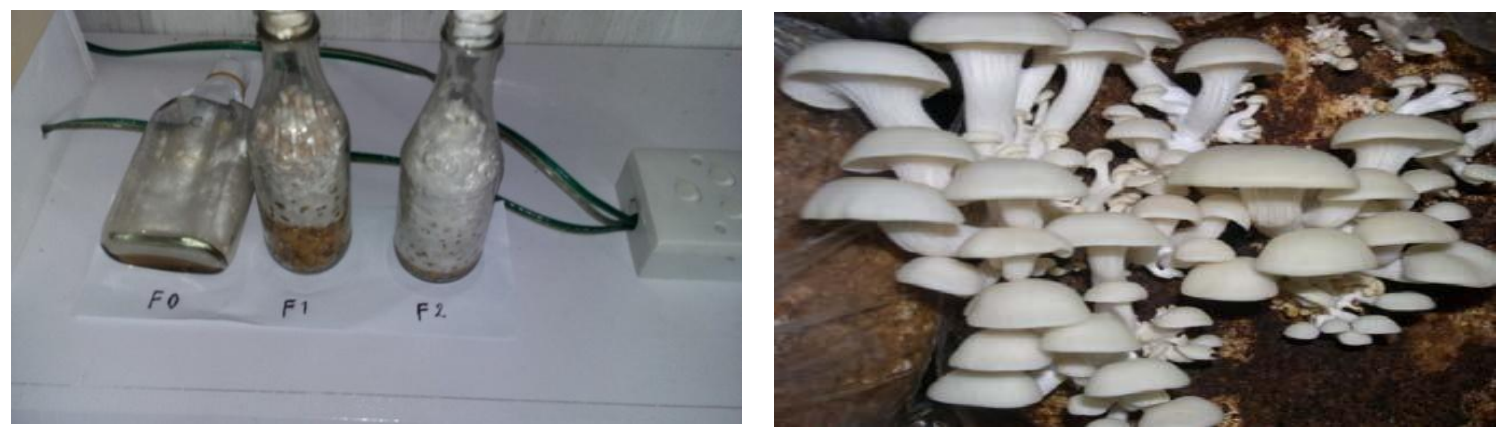

Figure 1. F0 seeds (left) and F1 oyster mushrooms (right)

Table 4. Level of Knowledge of Partner 2 Before and After the Training

\begin{tabular}{lll}
\hline Training & Before & After \\
\hline $\begin{array}{l}\text { The process of some types of } \\
\text { food from oyster mushrooms }\end{array}$ & Did not know & Understand and can apply \\
$\begin{array}{l}\text { The utilization of oyster } \\
\text { mushrooms baglog waste to be }\end{array}$ & \\
$\begin{array}{l}\text { compost fertilizer with EM4 bio } \\
\text { activator }\end{array}$ & & Understand and can apply \\
$\begin{array}{l}\text { The fermentation of compost } \\
\text { fertilizer from baglog waste }\end{array}$ & Did not know & Understand and can apply \\
\hline
\end{tabular}

The results of the community service activity show that the processing of oyster mushrooms into several types of food are still ongoing so that Partner 2 can increase their income. Also, the utilization of baglog waste of oyster mushrooms into compost is also an additional income for Partner 2. The implementation team of the community service strives to continually monitor Partner 1 and Partner 2 on an ongoing basis.

\section{Conclusion}

The community service activities, which have been conducted by the team from UNPAB, were found to be beneficial for Partner 1 from Bintang Mushroom farmer group. After the completion of the community service activities, Partner 1 has been able to produce F0 and F1 oyster mushroom seeds. In addition, Partner 1 also can choose high-quality mushroom seeds to be used as F0 oyster mushroom seeds.

This community service has also provided knowledge for Partner 2 on how to process oyster mushrooms into several types of food which can increase the income of Partner 2, Domas farmer group. Baglog waste of oyster mushrooms processed into compost fertilizer can reduce waste and environmental pollution. This compost fertilizer can also be applied to plants as organic fertilizer, such as vegetables, flowers, and other palawija crops. The farmers who have received compost fertilizer training might be advantageous as they can use this organic fertilizer 
to reduce the use of inorganic fertilizer. Partner 2, Domas farmer group, might also earn an additional income from compost fertilizer.

\section{References}

[1] Dinas Pertanian dan Peternakan Kabupaten Serdang Bedagai, 2014.

[2] Susilawati and Budi Raharja. 2010. Petunjuk Teknis: Budidaya jamur tiram (Pleourotus ostreatus var florida) yang ramah lingkungan. Materi Pelatihan Agribisnis bagi KMPH. BPTP Sumatera Selatan.

[3] BPTP, 2012. Produksi Pertanian Sumatera Utara, Medan.

[4] BPTP Kalimantan Timur, 2012. BudidayaJamurTiram dengan Menggunakan Media Jerami Padi. BalaiBesar Pengkajian dan Pengembangan Tekhnologi Pertanian, Badan Litbang Pertanian, Kementerian pertanian

[5] Maulana, E.S. 2012. Panen Jamur Tiap Musim, Jogjakarta

[6] Redaksi Agromedia, 2010. Buku Pintar Bertanam Jamur Konsumsi. Agromedia Pustaka 